\title{
THE MYTH OF SACRIFICE AND THE MYTH OF TRUTH IN SLOVAK LITERATURE AFTER THE SECOND WORLD WAR (J. C. HRONSKÝ: ANDREAS BÚR MAJSTER AND DOMINIK TATARKA: FARSKÁ REPUBLIKA AND ESSAYS)
}

\author{
Mária BÁtorová ${ }^{1}$ \\ (Slovenská akadémia vied, Univerzita Komenského v Bratislave)
}

Keywords: Slovak literary modern (two phases and lines), Christianity, myth of sacrifice, myth of truth, typological associations, historical context

Słowa klucze: słowacka literatura nowoczesna (dwa etapy i trendy), chrześcijaństwo, mit poświęcenia, mit prawdy, powiązania typologiczne, kontekst historyczny

\begin{abstract}
Mária Bátorová, THE MYTH OF SACRIFICE AND THE MYTH OF TRUTH IN SLOVAK LITERATURE AFTER THE SECOND WORLD WAR (J. C. HRONSKÝ: ANDREAS BÚR MAJSTER AND DOMINIK TATARKA: FARSKÁ REPUBLIKA AND ESSAYS). "PORÓWNANIA" 2 (23), 2018. VOL. XXIII, P. 35-46. ISSN 1733-165X. Hronský's work was written in Rome at the beginning of his journey until emigration in 1947/48. This, in terms of genre and content, is a distinctive form: an autobiographical tale through which the author erected a memorial. Andreas Búr embodies the capabilities and tragedy of the author. The sacrifice for the people who kill him bears in itself a Christian pathos and at the same time the extinction of everything the author was. His character remains in the memory of the people as the myth of an ethical act. Tatarka's work was written in Slovakia in 1948. This critique of conventional Christianity, which has tragic consequences for a defenceless woman and her children, is linked with criticism of the author Hronský in the novel Andreas Búr Majster. The movement towards the myth of truth begins in Tatarka immediately at the time of thawing after Stalin's death in the essay "Démon súhlasu" (The Demon of Conformity) and ends in the author's 19 years of "life in truth" and the victim of a life without civil rights.
\end{abstract}

1 E-mail: maria.batorova.sav@gmail.com 
Abstrakt: Mária Bátorová, MIT POŚWIĘCENIA I MIT PRAWDY W SŁOWACKIEJ LITERATURZE PO DRUGIEJ WOJNIE ŚWIATOWEJ (J. C. HRONSKÝ: ANDREAS BÚR MAJSTER AND DOMINIK TATARKA: FARSKÁ REPUBLIKA AND ESSAYS). „PORÓWNANIA" 2 (23), 2018. T. XXIII, S. 35-46. ISSN 1733-165X. Hronský pisał swoje utwory w Rzymie na początku emigracji w latach 1947-1948. Pod kątem gatunku i zawartości jest to odrębna forma: opowieść autobiograficzna, w której autor tworzy memoriał. Andreas Búr jest ucieleśnieniem możliwości i tragedii autora. Poświęcenie za ludzi, którzy go zabijają, samo w sobie ukazuje chrześcijański patos, ale również symbolizuje koniec tego, kim był autor. Jego osoba pozostaje w pamięci jako mit aktu etycznego. Utwory Tatarki zostały napisane w roku 1948 na Słowacji. Jest to krytyka konwencjonalnego chrześcijaństwa o tragicznych konsekwencjach dla bezbronnej kobiety i jej dzieci, nawiązująca do krytyki Hronský'ego jako autora powieści Andreas Búr Majster. Mit prawdy ukazuje się u Tatarki w okresie odwilży zaraz po śmierci Stalina w eseju Démon súhlasu (Demon zgody). Tendencja ta kończy się po 19 latach „życia w prawdzie” i bycia ofiarą życia pozbawionego praw obywatelskich.

In the presented study we will deal with two trends of Slovak prose from the inter-war period - that is the Slovak modern literature, through the texts of J. C. Hronský and D. Tatarka. The interpretation of both writers emerges from specific texts, perceives them as the contexts of the authors, which have, in addition to them, other contexts as well (historical, sociological, philosophical and others). In the process of an interpretation so constructed, a more complex interpretation ultimately arises. The final return to the text is then a verification process of the correctness of the interpretation, because the text has a corresponding value. ${ }^{2}$

With regard to the history of Slovak culture, which has developed under five political hegemonies (Bátorová 2014) myth has an exceptional position, and not only from the times when the myth of the nation was being formulated and demonstrated revolutionarily everywhere in the 19th century; there is also the myth of its own identity, which has lived in the defence of the language since the extinction of Great Moravia. ${ }^{3}$ This is the myth of education, knowledge of one's own separate culture, signs of which are an independent common language, ${ }^{4}$ the shared territory of Upper Hungary up to 1918 and Slovakia within Czechoslovakia in the inter-war period and after 1945 . We attempt to show the last statement by analysing the texts in this study.

2 A new model of research i.e. the communication theory of contexts and interpretational theory of contextualization was introduced into the literary environement at the World Congress of Comparative Literature in Vienna, in July 2016. (Studies are in press). Thus, both monographs on the subject are built theoretically on the author of this study (Bátorová 2000; Bátorová 2012).

3 In the period of Great Moravia (further GM), in 863, two scholars from Solún arrived to the territory of today's Slovakia, at that time GM, on the invitation of Prince Rastislav. The philosopher Cyril and the jurist Methodius. They brought the Glagolitic script and spoke the liturgy to people of this territory in their own language. However, they were invited to Rome before the pope, to justify this act. Cyril defended Old Slavonic into which he had translated the Bible, against those promoting only three-languages for the Bible. The pope permitted Old Slavonic as a third cultural language.

4 Two codifications of the Slovak language: 1. A. Bernolák 1787; L'. Štúr 1843 - 46. 
The year 1945 and the development of Slovakia in the renewed Czechoslovak Republic (the Czechoslovak Socialist Republic after 1948) was influenced by the inter-war evolution in the first Czechoslovak Republic and in the Slovak Republic, which was a vassal state of Germany. The Slovak modern statehood began during the political relations in two extremely different states in 1918 - 1919 (with a memorandum declaration and the signatures of 500 Slovak intellectuals). The myth of freedom and independence was supported by its own state language and its own institutions; however, the pragmatic idea of Czechoslovakism doubted this, and thus there was a movement towards assimilation. Non-observance of the 13 points of the Pittsburgh Agreement created tension and political radicalism over time. But Slovak intellectuals expressed themselves in unity ${ }^{5}$ and thus also proceeded to the Slovak Republic of 1938 - 45. In the literary magazines Elán, Slovenské pohl'ady and Tvorba a Kulturra they came out in unity for democracy. ${ }^{6}$

Still during the London residence of E. Beneš, Czechoslovakia's president in exile, he asked Moscow for help in punishing the Slovaks after the Second World War (Letz 263). Soviet assistance remained, however, not only with processes with the intelligentsia of the Slovak Republic, but also the monster processes of the 1950s, the so-called bourgeoisie nationalists. Clementis was hanged, while L. Novomeský, G. Husák, Ivan Horváth and others were sentenced to long-years of hard prison time. In the 1950s power forbade the activities of bishops and priests. They were sentenced to many years in the Jáchymov mines, the Leopoldov prison and the like. Alongside this hard crackdown, the myth of the SNP and the Soviet Army as liberator was deservedly elevated, and the myth of the renewal and building of the Czechoslovak homeland also grew.

And in this short reconstruction of the development and history of Slovak culture, a basic sign of which was the parallel existence towards official politics and culture, that is mere existence despite everything that happened, it is necessary to be aware that Christianity, faith and religious myths, as well as living Christianity, i.e. the ability to sacrifice oneself for higher aims, had fertile soil here, and they all played a role in the nation's development. Writers romantically endeavoured to directly keep Christianity alive. Thus, we perceive myth from this point of view in particular $^{7}$ (Hübner 74).

The authors J. C. Hronský (1896 - 1960) and D. Tatarka (1913 - 1988) embody in their existence and works two basic aesthetic-ethical lines in Slovak literature. Their

5 Testimony of this was a resolution from the Congress of Slovak Writers from 1936 which included the signatures of all participants regardless of their political and religious affiliations unified for democracy and against war. The meeting took place in Trenčianske Teplice.

6 In 1940, a sharp anti-war novel called Olovený vták was published by M. Figuli in Slovenské pohl'ady, a journal that was considered as undemocratic in the times of socialism. See: Bátorová, M.: Roky úzkosti a vzopätia, Causa editio, 1992, pg. 102 - 105.

7 "According to Bachofen the original chthonic or telluric myth transforms into the Homeric; thus, life melts from the dark to the light (-) This movement perfected Christianity, in which God became a spirit." For more detail, see Hübner (1985: 74). 
difference consists in a different narration, strong in both and yet completely different. The connection between both writers is not genetic (we never find any signs of mutual contact) but it is typological ${ }^{8}$. The myth of Christianity perceived critically, and nevertheless as something firm and in pure form necessary, is evident in both. Likewise the myth of the nation. Not generally, but specifically in both authors this involves the Slovak national society, because at the time of the origin of the work (and up to 1993 - to the origin of the Slovak Republic) Slovakia was not an autonomous state.

There is a nearly twenty-year difference between the two writers. Both studied pedagogy, but Hronský at the time of Magyarization and the First World War at the Pedagogical Institute in Levice, from where after completing his studies he was called directly to the Italian front at the end of the First World War. He experienced a hard shock there, and the madness of Pisár Gráč (Gráč, the Clerk, 1940) is a processing of this experience. He overcomes the state of personal entropy in the novel in that he binds himself to the good which his happy childhood in central Slovakia, in Zvolen, left in him. Tatarka was also affected by the consequences of the First World War, since his father never returned from it. This loss remained a kind of nightmare, and as a consequence of the uprising in the Second World War he lost a young son, as did his beloved sister. Death was a kind of escort of Tatarka's work from the very first stories. Therefore, Slovak literary scholarship saw him as an author who belonged in the existentialist current. Tatarka, however, had this symptom in his works before the official origin of Existentialism in France (Forgáč 2013).

Both authors were advocates for the national culture and freedom. Hronský from 1939 was the head of Matica slovenská which rose to a world-class level (the establishing its individual departments which meant establishing research that is the Slovak Academy of Sciences (SAV) in 1942, Neografia - a printing press equipped with the most modern machinery, etc.) $)^{9}$. He attended to the level of education, writing in all genres himself (including readers for grades first year up through school-leaving exams illustrated by Martin Benka)... and he dealt only culture, not politics. Tatarka completed one year at a seminary in Nitra and then entered a grammar school in Trenčín after which he studied at Charles University and the Sorbonne. At the time of his studies in Trenčín, he headed the L'udovít Štúr Association. At the time of Hronský's most significant activities, Tatarka taught at a grammar school in Martin and in Žilina and debuted with the collection of stories V úzkosti hladania (In the An-

8 Dionýz Ďurišin, from whom Slovak comparative literary scholarship still draws on today, differentiated genetic and typological associations between the authors, comparative literary works and literatures. The genetic association is the contact demonstrated in correspondence, preserved in archives, etc., while typological relations are independent of direct contacts.

9 The Germans requested from Hronský that the printing press of Neografia be disassembled and transported to the Third Reich. Hronský disobeyed the order and had the train loaded with scrap metal. 
guish of Searching). He took part in the Slovak National Uprising (SNP) in Banská Bystrica and was a part of the famed march over the mountain Chabenec.

As writers, these men could have met, but we find no indications of such a meeting. Their paths were completely different after 1945, however. J. C. Hronský, disappointed by his own people who in Martin shut him up for one night into a blood-spattered cellar of the former Gestapo, emigrated with his family. ${ }^{10}$ He travelled with other cultural workers through Austria, where he earned his living with his "second language" - a paintbrush. Subsequently, he was imprisoned in Italy from which he was freed by the former ambassador in the Slovak Republic on the intercession of Karol Sidor. He got the chance to leave, but not to America ${ }^{11}$ where he would have prospered, but to Argentina where he endured hardships and was rarely able to devote himself to writing and died relatively young ${ }^{12}$. D. Tatarka outlived Hronský by nearly 30 years, always in Slovakia; however, the thrilling story of his life is equally adventurous: Communist power took away his freedom and for a long time he had to subject himself to it, as well as permanently disobey it in his works. The 1960s was a time of liberation in Slovak culture, heading towards Dubček's proclaimed socialism with a human face. Tatarka spoke on Námestí SNP in Bratislava after the arrival of the Warsaw Pact forces into Czechoslovakia, and the students held him aloft in their hands. He then returned his accolades and lived for 19 years without a passport and civil rights in Bratislava, until his death in 1988.

Such is the historical context of both writers in brief. Their lives are also, in such a brief record of events, an image of the relationships of the complicated political and cultural development of Slovakia in the scope of the Czechoslovak Republic and the whole 20th century.

Now let's focus on the myth of sacrifice - an autobiographical motif: The novel Andreas Búr Majster has a distinctive hybrid organization. It takes the form of a tale and at the same time is an autobiographical novel of the author ${ }^{13}$, objectivized stories full of mysterious tension. Rome as the mecca of Christian culture was the penultimate stop on the life path of Hronský, but his situation was tragic, because he never mastered the language of the country. As a writer for whom language is fundamental, he was in effect dead. The name of the character which stands in the name of the novel is symbolic: the Latin form Andreas indicates antiquity, Búr the

10 At the same time testimony exists regarding Hronskýs loyalty to the uprising: "I never had any doubts about his (Hronský) anti-fascist thinking. He demonstrated it more than once in the struggle to preserve the clean slate of Matica slovenská against fascist tendencies of representatives and political exponent for the Slovak Republic." This is the testimony of Hirner (1992: 247), a colleague of J. C. Hronský.

11 In the 1930s, Hronský organized a several-months journey to America. He imported from Slovakia many books, folk costume, folk art... they undertook a lecture tour. Hronský was to have everything there prepared, similarly as when Thomas Mann travelled to America.

12 In 1992 Hronský and his wife's remains were transferred to the National Cemetery in Martin.

13 The genre dividing of the work, especially the novels, see: Bátorová (2011: 238). 
character and Majster evokes knowledge or even God (15 - symbols). One of the introductory scenes of Andreas Búr Majster plays out in a church where Andreas offers thanks by a prayer - a song (Hronský 2008). The tragic conclusion of the novel is also framed by two prayers: the fictional prayer of the already dead Búr, alias the writer, and a still living character who admits guilt, declares himself guilty for the death of others (in an epidemic of cholera) and wants an act of penance:

"God, indeed, I know why she left (Lucia died, note: MB)... God, after all, you're omniscient, you know why I quit singing... I renounced myself, but I didn't abide by everything." (p. 222)

In his thoughts he was namely with Amália Privitzerová who was pregnant with his child. The prayer is a long internal monologue, after which Búr sets off to the village in order to help protect it against cholera, where for his unselfish help people pay him back such that they shut him into the church, and when instead of the deceased priest he begins to preach to them about guilt for their sins, and thus responsibility for the cholera and death, people ascribe this terrible epidemic to him; a hysterical woman censures him and flies at him:

"The wheelwright's wife shouted, and this lifted her, certainly her shrouded mind, because she ran towards Búr and hurled herself at him with a scream, from which nothing could be understood... then two other shouted and a delusion seized the people before the Ráztočno church. A raging came upon the people... He fell (Andreas Búr, note: MB) from a height onto a sharp stone, and cracked his skull .... But Andreas Búr died before the church doors, because a black death, the sort he was in search of, wasn't his fate. He was redeemed. They buried him and eleven others together, and this was very strange, as the white Andreas Búr Majster stood out too much among other black deaths.

Perhaps that's why they didn't forget him...

Andreas Búr did not die.

The story kept him alive." (pp. 226 -- 227)

The prayer of the dead Búr:

"You are just, God, and merciful. Now I know the things I would not have understood at the sawmill. How would we have lived there...? How much would we have suffered? Only you yourself know how much we would have sinned! Thus, you abandoned Lucia's dream in the highest happiness, and you were merciful towards me, too; you took the burden from my shoulders, which I would have had to bear for a long, long time... I'm grateful to you, Lord, that you committed me to suffering" (p. 227)

The place of this final prayer of the novel, where the narration of the character is identical with the narration of the author, indicates not only an evident faith in the 
afterlife, but at the same time is proof that this work is autobiographical and that the author, until now living in Slovakia, who persistently looked for God, (also in a work written in the beginnings of emigration: Predavač talizmanov Liberius Gaius od porta Collina) (Hronský 2008) was only searching; he discovered God, came to terms with his fate as an emigrant, dead for his nation, which actually killed him. And he meekly ascribed guilt to his own offenses - his own sins. The life situations of the novel are, as in all works of Hronský up to that time, replete with real life. He didn't just blame the unthinking, and therefore murderous mass of people; he rather defended and thus forgave them. The Christian perception of reality and self-reflection,which lead one to sacrifice for others, have been a continually present tradition of Slovak literature from its beginnings, through the inter-war period, and as we'll see also in the work of Dominik Tatarka, but in a different way. Therefore, Tatarka forms a chronological, in part parallel, and qualitatively entirely different line of modern Slovak prose. Tatarka saw the nation as a mass, that is the undifferentiating, unthinking assembly, as disunited, and he considered unity as a positive attribute in the essay "Kultura ako obcovanie" (Culture as Communion, in Úvaha o pohybe národa) (Tatrka 1968: 6-8):

"I think that it's very imperative that we within ourselves and especially in young generations renew the consciousness of the entirety of the national culture. Not only artists express themselves in culture. The entire nation expresses itself in culture." (p. 8)

Tatarka introduced another of his key emblems - the unity of culture. It is evident that the social as well as the personal living situation of the author graduated into the dramatic outputs of the stirring days of 1968, to which this essay belongs. Tatarka provides a definition of culture in it:

"Culture is thus a refreshing, always festering state of awareness. ... The trunk of national culture is the culture of commonality, social culture" (p. 8).

He declared the measuring of cultureness according to "mass consumption attendance" as absurd. Therefore, he sharply rejected all petrification of cultural phenomena, which then came to people as if ready-made through official instructions. Just before then he criticized organized criticism. He saw every single person and everything "by which the nation is expressed" incorporated into the cultural process (not to art). His criticism turned towards the template-stamping uniformity and unification of taste that socialism brought.

\footnotetext{
"Yes, we liberated this nation from everything, its forests, its soil, its responsibilities. A place of God and the saints, 'those up there settled in the heavens. ... Culture is for us communion. It is discourse. It is an understanding. It is a summary of deeds. It is a national activity. It is the sum of all of its expressions. ... The question of socialistic culture is concentrated on questions of rights
} 
and freedom of expression, on the question of rights and freedom of assembly, rights, which every constitutional democracy guarantees. It guarantees them on paper; in reality it curtails them" (pp. 6-8).

The review of socialism and its working on the national culture, as Tatarka presented it here in his essays, was sufficient for him to lose his civil rights, which were so important to him, until the end of his life. He lost civil rights for personal liberty which, however, he protected for himself and his followers in internal emigration.

At this time Tatarka had still not stated the "high" programme of morality which would have "created" him. He did not have the necessary timelessness which would lead him to moral acts. He lived simply in the present moment. His ability to express his own decisions, will and opinion at just the right moment and thus influence events; an ability so strong in Slovak men of action such as Štúr, Štefánik or Tatarka, is not expressed further by the use of power. It is as if these men were only the makers of the path, of the present moment, "performers" and conquerors, who were not interested in acquiring power or position, as if they would not know what to do with it if they had it. They had an idea - a vision of events, but not of status. After the action they were unable to capitalize on it, to shore it up and to fill in with dynamic creation of values not only the path, but also the places. Therefore, their fates are those of martyrs.

Tatarka believed in the differentiated identity of nations. From his spiritual instructor M. de Unamun he adopted a type of existentialism with a quixotic faith in the rebirth of human society, based on the philosophy of Pascal, Kierkegaard and Nietzsche, and tending toward personalism. Among period poets, he explicitly names Shklovsky and his theory of defamiliarization. Tatarka's sensibilities, coming from his domestic Catholic upbringing and strong attachment to a deeply religious mother, through religious universalism at a certain moment - enabled him during his studies in Prague and Paris to easily connect left-wing Marxist-orientated ideas of freedom as well as French sensualism. The national upheaval at the end of the 1930s was also repeated several decades later. An emphasis on identity, the question "Who am I", was also key in the 1960s (Zervan 1995).

Tatarka is interested in the position of the morality of a conventional Christian life in the novel Farská republika (1948). (We must also only paraphrase, i.e. not quote the text, because this material is verbose and would serve for an independent study). The autobiographical character Tomáš Menkina meets his girlfriend from childhood on the street, who after the death of her partner - a revolutionary - who was killed, has just returned from Ostrava; she is pregnant and her older child walks alongside her. Tomáš sends her to his own mother who lives alone in a house. The mother then sends her to confession, but the priest wants her to apologize for her life without marriage and she cannot; she does not get absolution and the mother expels her from the house. The woman dies together with her child under hard conditions 
in the hospital. This criticism of conventional religion in the novel is linked with criticism of religious practice functioning at schools (spiritual exercises through public radio, etc.), as well as the emerging Communist practice in the figure of the communist Ličko who is depicted ironically, Tatarka avoided this novel being considered as generalized. Tatarka thus unmasks and diagnoses one after another the ongoing political totalitarianisms, "brown" (Farská republika) and "red" ("Démon súhlasu" from 1956) totalitarianism ${ }^{14}$.

We find the myth of Christianity and the desire for the veracity of life in Tatarka in the essay "Obec Božia" (The Community of God). (Smena, 7 May 1968, p. 3., in the archive - in the manuscript found in the form "Božia" (God's, capital letter), in the paper Smena with a small " $b$ "). Here it's possible to read the concentrated democratic principles linked to Christian universalism. We observe a genetic association with the work of A. Camus and with the work Civitas dei from St. Augustine. The principles of the New Testament - exemplary cohabitation among people as the highest principle, as a guarantee of quality life and inter-human relationships (Bátorová 2012: 181-199) ${ }^{15}$.

The Christian aspect, as we have already emphasized, plays an important role. Alongside the diagnosing of political systems and their functioning he speaks about culture which he links with Christianity:

"Does a Renaissance of religious Christian sentiment threaten us? And would this be a danger to socialism in the Republic? ... the starting point and end point of each revitalizing process in society is culture. Culture in its extreme wealth of forms and expressions is as wide as life; it is identical to the fate of nations and humanity, its significance and fulfilment, its 30-40-thousand-year eternity. Culture remains sovereign as man-God, as the anthropological. For a politician capable of greater and permanent conceptions, of designing a programme of national and state activities, for a politician, just as for a philosopher, the starting point and inspiration must be culture, including national history. From not respecting the sovereignty of culture as the meaning and oneness of life, from its misunderstanding, from its abuse, from its rationalistic or utilitarian representation, a dehumanized derivative Americanism was produced, the dehumanized deity of an

14 A similar analysis in the fourth chapter of the first scholarly monograph on Tatarka is found in Bátorová (2012).

15 The title "Obec Božia" (Community of God; in the name of the essay presented also in capital letters) comes from Augustine Aurelia just as Albert Camus borrowed this from the Bishop of Hippo, which Tatarka himself points out elsewhere. This, however, is only a title that both authors used. Augustine's life and beginnings are relevant for Tatarka not only by the period of apocalyptic transformations, similar to the 20th century, but also Augustine's fate of a person responsible for the death of many defenceless Christians (among whom was also his own mother) before the temple of Bishop Ambrosia, further the outstanding ability to rhetorically convince, as well as the fate which he himself selected - help for people and awaiting death in a city surrounded by the Vandals. Tatarka's fate is very similar; therefore, Tatarka took this allusion from history. 
almighty state.... Against a background of Christian culture, against a background of millennia, against a background of eternity, everlasting struggles, our republic appears to me as a community of God. This is also the meaning of our present democratizing effort." (p. 10 mss.)

In relation to the evident membership in the Church, Tatarka left it under pressure from power, but at the time of "internal emigration", he returned to it like the prodigal son. In the Monument of National Documents, where the still unprocessed legacy of D. Tatarka resides, we find a document in which the author writes in his own hand:

"Fathers of the Church, I have erred in my ways by leaving the Church. Please accept me back amongst you. Bless the earth in which I am placed. Sing the Latin refrain above me: Circum dederum me. Thank you. Dominik Tatarka."16

On his final journey, on 10 May 1989, Dominik Tatarka was accompanied by and buried by the controversial priest Anton Srholec.

\section{Conclusion}

Two intellectually strong individuals and artistic identities - the novelist and involved citizen Jozef Cíger Hronský and the novelist, essayist and involved citizenperformer Dominik Tatarka - are presented in the framework of the Slovak modern. In their works, a current in the development of the Slovak literary modern is clearly differentiated, which after the initial phase of predominately poetry (I. Krasko, J. Jesenský, I. Gall, V. Roy and others) ascends into prose genres (J. C. Hronský, M. Urban, J. Hrušovský, G. Vámoš and others) after the First World War. This is comparable to the classics of the world modern (Š. Márai, F. M. Dostoyevsky... ${ }^{17}$, however, Hronský's developmental occurs in the opposite order: his work amounts to its poetics, i.e. broken, partial, rhapsodical and a line of awareness, which is equally strong as the evident subject etc., in the paradigm of the world modern subsequent phase after the classical that is the peak phase of the modern.

D. Tatarka, who debuted in 1942, thus 20 years after Hronský, recorded in his poetics another phase of the Slovak modern. While Hronský's narrator is still omniscient and even in autobiographical novels (Proroctvo doktora Stankovského, 1935, Pisár Gráč, 1940, Andreas Búr Majster, 1948), the author dares not identify the character with the narrator, Tatarka doesn't hide the autobiographical nature and essentially everything he writes has an autobiographical character.

16 LA PNP, Fond Dominik Tatarka, oddíl: Rukopisy vlastní. 30/C/21.

17 See in this regard the comparison with the work of Dostoyevsky, Márai, Gombrowicz... In: Bátorová, M.: Hronský a moderna... 
Hronský completely evaluated his situation realistically in the novel Andreas Búr Majster. After the unprecedented blossoming of Slovak culture that he deserved credit for without getting mixed up in politics, it was politics that grounded him and as a strong personality shunted him aside. He was effectively dead in emigration for the domestic culture and literature and his own people, for whom he'd written and for whose upheaval he worked, caused this. For this sacrifice which notionally cost his him life, he thought up a mysterious justification: it was the result of his own sins by which he actually forestalled death. Christian universalism and the movement to catharsis in the novel Andreas Búr Majster where Búr acts out penance through his efforts for others and is rewarded by salvation, this base keeps him forever alive in the awareness of people - by means of a myth. That's why Hronský selected the genre of the tale and thus also paid tribute to a literarily pure genre.

Tatarka's path to penance and identification with himself lasted almost exactly as long as that of Hronský who departed into emigration as a 50-year-old. At the same time on his path Tatarka, as a 50-year-old, decided to express his political opinion openly, choosing a "life in truth" 18 , and he became a legend of his time and a myth of a truthful life.

The myth of sacrifice and the myth of truth in Slovak literary art is associated with the rising up against power, the bravery and ability of sacrifice for others in line with one's own convictions, thus by a strong personal identity.

Transl. David McLean

\section{REFERENCES}

Bátorová, Mária. J. C. Hronský a moderna. Mýtus a mytológia v literatúre. Bratislava: Veda, Ústav svetovej literatúry SAV, 2000.

Bátorová, Mária. Slovenská literárna moderna v spektre svetovej moderny (Jozef Cíger Hronský). Bratislava: Vydavatel'stvo Matice slovenskej, 2011.

Bátorová, Mária. Dominik Tatarka slovenský Don Quijote. Sloboda a sny. VEDA: Bratislava, 2012.

Bátorová, Mária. Slovak literature and culture from the "postcolonial" perspective. Primerjalna književnost, letnik 37, št 3, Ljubljana, December 2014 (časopis CC).

Forgáč, Marcel. Existencializmus a slovenská literatúra (interpretácia foriem existenciálnej rétoriky v dielach Dominika Tatarku, Jána Johanidesa a Rudolfa Slobodu). Vydavatel'stvo Prešovskej univerzity, 2013.

Havel, Václav. The Power of the Powerless in Open Letters: Selected Writings: 1965-1990 Edited and Translated by Paul Wilson, 1978.

Hirner, Aleksander. Matičná myšlienka. Bratislava: Slovensky, 1992.

18 Havel V.: In 1978 Václav Havel wrote an approximately 80-page essay "The Power of the Powerless" where the concept of "life in truth" (J. Patočka) is presented. 
Hronský, Jozef Cíger. Andreas Búr Majster, Zobrané spisy, zväzok VII. Bratislava: Matica slovenská, 2008. Hübner, Kurt. Die Wahrheit des Mythos. München: Verlag C. H. Beck, 1985.

Letz, Róbert. Slovenské dejiny V (1938 - 1945). Liteárne informačné centrum, 2012.

Tatarka, D. Kultúra ako obcovanie (Úvaha o pohybe národa), Kultúrny život, 23, 1968, no. 31, pp. 6 - 8. Zervan, Márian. Gramatika úvah o človeku. Gramatiky filozofických, estetických a výtvarno-teoretických dialektov, sociolektov a idiolektov 60. rokov. In: Šest'desiate roky v slovenskom výtvarnom umení. Slovenská národná galéria, Bratislava 1995, pp. 28 - 37. 